\title{
SISTEM INFORMASI EKSEKUTIFF (SIE) UNTUK MEMANTAU GANGGUAN GARDU LISTRIK BERBASIS LOKASI PADA PLATFORM ANDROID (Studi Kasus: PT. PLN Area Bandung)

\author{
Faisal Prasetya Pangestu1, Fitri Mintarsih ${ }^{2}$, Nenny Anggraini ${ }^{3}$ \\ ${ }^{1,2,3}$ Universitas Islam Negeri Syarif Hidayatullah Jakarta \\ mail: faiz_holic99@yahoo.com, mintarsihftr@gmail.com, nenny_a@yahoo.com
}

\begin{abstract}
ABSTRAK
Berdasarkan hasil penelitian dan wawancara dengan Manager dan Asisten Manager PT. PLN area Bandung, pengambilan atau permintaan laporan data aset masih bersifat internal meskipun sudah menggunakan aplikasi pengolahan Sistem Informasi Distribusi (SIMDIS). Akan tetapi masih terdapat kelemahan, seperti pengolahan data aset maupun data laporan yang masih bersifat internal, sehingga proses permintaan data laporan tersebut hanya bisa diakses di lingkungan kantor PLN Area Bandung dan oleh orang-orang tertentu yang memiliki hak akses ke SIMDIS. Oleh karena itu untuk mengetahui persediaan aset dan data laporan jaringan listrik pada PT. PLN Area Bandung masih mengalami kesulitan sehingga perbaikan jaringan listrik mengalami keterlambatan. Penelitian ini didasari oleh penelitian terdahulu yang berjudul Rancang Bangun Sistem Informasi Eksekutif Penjualan pada PT. Penerbitan Pelangi Indonesia yang menyimpulkan bahwa memungkinkan jajaran menejerial melakukan monitoring dan pangambilan keputusan terhadap laporan-laporan tersebut. Aplikasi ini dikembangkan menggunakan platform android sebagai front end serta php dan MySql sebagai back end. Aplikasi ini menggunakan metodologi sistem incremental yang terdiri dari 5 fase yaitu Komunikasi, Perencanaan, Modeling, Konstruksi, Deployment dan perancangannya menggunakan Unified Modelling Language (UML). Berdasarkan hasil observasi, maka diperoleh kesimpulan bahwa aplikasi yang dibuat harus mampu membantu mengetahui lokasi gangguan listrik, menampilkan fitur notification apabila terdapat laporan-laporan perusahaan yang masuk ke sistem, dan memungkinkan menejerial, user area dan user unit dapat menginput data aset dan mengetahui persediaan aset.
\end{abstract}

Kata Kunci: Sistem Informasi Eksekutif, SIG, Notification, PHP, MySql, Android, Incremental, UML

\begin{abstract}
Based on the results of research and interviews with the Manager and Assistant Manager of PT. PLN Bandung area, decision or request data reports still are internal assets while already using the application processing Distribution Information System (SIMDIS). However, there are still weaknesses, such as data processing and data assets are still reports are internal, so the process request report data can only be accessed in an office environment PLN Bandung Area and by certain people who have access rights to SIMDIS. Therefore, to determine the asset inventory and report data on the electricity network PT. PLN Bandung area is still experiencing difficulties so that repair the electricity network has been delayed. This study is based on previous research, entitled Design of Information Systems Sales Executive at PT. This prompted the researchers to build applications that can provide ease in informing the reports of interference in the form of asset data and corporate reports in real time and up to date based mobile by using notification and GIS. This application was developed using android platform as well as the front end php and MySQL as the back end. This application uses the methodology of incremental system that consists of five phases of Communications, Planning, Modeling, Construction, Deployment and its design using the Unified Modeling Language (UML). Based on observations, it could be concluded that the application is made should be able to help determine the location of a power failure, display features a notification when there are reports of companies that get into the system, and allows managerial, user area and user units can enter the data assets and determine the stock of assets.
\end{abstract}

Keywords: Executive Information Systems, GIS, Notification, PHP, MySql, Android, Incremental, $U M L$ 


\section{PENDAHULUAN}

Perkembangan suatu negara sangat bergantung pada peningkatan kualitas sumber daya manusia dan sumber daya alam. Untuk mewujudkannya dibutuhkan sebuah energi, tenaga listrik adalah salah satunya. Kebutuhan masyarakat terhadap listrik sangatlah penting, untuk itu peran pembangkit tenaga listrik harus dioptimalkan, dalam hal ini PT. PLN (persero) selaku suatu perusahaan yang bergerak dalam bidang bisnis penyediaan dan penyaluran listrik.

Berdasarkan data yang diperoleh dari website PT. PLN (Persero) yakni http://www.pln.co.id/, kenaikan jumlah pelanggan dan kapasitas pembangkitnya sejak 30 tahun terakhir PLN berkembang sangat pesat. Pertumbuhan kebutuhan listrik yang terus meningkat maka PLN dituntut untuk meningkatkan kualitas dalam hal penyediaan dan pelayanan kepada masyarakat.

Peneliti telah melakukan penelitian di PT. PLN (Persero) Area Bandung yang merupakan pusat pelayanan listrik di Distribusi Jawa Barat dan Banten (DJBB). Menurut data perusahaan APJ Bandung per November 2011, luas wilayah pelayanan yaitu 99,15 $\mathrm{km}^{2}$ dengan 34 kecamatan dan jumlah pelanggan total 544.842 yang terdiri dari 500.711 pelanggan rumah tangga, 2.670 industri, 33.928 bisnis, 7.533 sosial serta 2.275 untuk instansi pemerintahan.

PT. PLN Area Bandung selaku penyedia kebutuhan listrik dalam skala besar maka diperlukan peningkatan kinerja. Salah satunya adalah dengan pengelolaan data aset. Untuk itu, diperlukan suatu aplikasi yang mengelola data aset dan transaksi lainnya yang berhubungan dengan pelayanan kepada pelanggan. PT. PLN Area Bandung sendiri telah memiliki aplikasi pengelolaan Sistem Informasi Distribusi (SIMDIS) yang berfungsi mengelola data aset perusahaan (Gardu Induk, Gardu Hubung, Saluran Udara Tegangan Menengah (SUTM), Saluran Kabel Tanah tegangan Menengah (SKTM), Jaringan Tiang Rendah (JTR) sampai dengan jaringan listrik rumah tangga beserta laporan gangguan) yang berbasis web internal.

Berdasarkan hasil penelitian dan wawancara dengan Manager dan Asisten Manager PT. PLN area Bandung, pengambilan atau permintaan laporan data aset masih bersifat internal meskipun sudah menggunakan aplikasi pengolahan Sistem
Informasi Distribusi (SIMDIS). Akan tetapi masih terdapat kelemahan, seperti pengolahan data aset maupun data laporan yang masih bersiffat internal, sehingga proses permintaan data laporan tersebut hanya bisa diakses dilingkungan kantor PLN Area Bandung dan oleh orang-orang tertentu yang memiliki hak akses ke SIMDIS. Oleh karena itu untuk mengetahui persediaan aset dan data laporan gardu listrik pada PT. PLN Area Bandung masih mengalami kesulitan sehingga perbaikan gardu listrik mengalami keterlambatan.

Hal ini menghambat PT. PLN Area Bandung dalam meningkatkan kinerjanya, seperti pelayanan menjadi terganggu dan proses pengawasan terhadap gangguan tersebut menjadi terlambat sehingga pelayanan konsumen terlihat menjadi buruk, dan PT. PLN area Bandung gagal mencapai target yang diinginkan.

Dengan keterbatasan yang ada, dibutuhkan sebuah aplikasi yang menggunakan teknologi Sistem Informasi Geografis (SIG) dan menggabungkan antara GPS (Global Positioning System) dan location based service. SIG yang bekerja menggabungkan peta dengan sistem informasi dan menggunakan visualisasi. Sebagai suatu alat bantu, SIG dapat digunakan oleh manajemen untuk mengetahui posisi lokasi terjadinya gangguan listrik secara up to date, pelaporan kinerja yang dibutuhkan secara cepat untuk mendukung PT. PLN Area Bandung dalam meningkatkan kinerjanya.

Berdasarkan permasalahan tersebut maka penulis melakukan penelitian yang berjudul

"Sistem Informasi Eksekutif (SIE) Gangguan Pada Gardu Listrik Berbasiskan Lokasi pada Platform Android (Studi Kasus PT.PLN Area Bandung)".

Berdasarkan latar belakang yang telah diuraikan di atas maka peneliti mendapati permasalahan yang ada antara lain:

1. Bagaimana mengolah data peta gardu listrik kota Bandung sehingga GPS dapat menunjukan lokasi gardu listrik yang mengalami gangguan?

2. Bagaimana membuat Sistem Informasi Eksekutif yang memberikan laporanlaporan penting?

3. Bagaimana mengetahui persediaan aset jaringan listrik pada PT PLN Area Bandung untuk mengatasi masalah gangguan listrik? 
Sesuai rumusan masalah di atas peneliti membatasi ruang lingkup penelitian antara lain:

1. Objek yang terdapat pada sistem informasi ini hanya mencakup luas wilayah PT PLN APJ Bandung, gardu listrik Kota Bandung.

2. Aplikasi ini hanya digunakan oleh tingkat manajerial PT PLN Area Bandung.

3. Aplikasi ini hanya dikembangkan untuk platform android.

4. Data laporan, hanya meliputi data Gardu Induk, Penyulang, dan Saluran Udara Tegangan Menengah (SUTM) yang akan diterapkan dalam Sistem Informasi Geografis (SIG).

5. Sistem Informasi Geografi (SIG) hanya sebagai tools dalam pembuatan aplikasi ini.

Tujuan dari penelitian ini adalah:

1. Merancang aplikasi yang menggunakan teknologi GPS dan navigasi.

2. Merancang aplikasi dengan menggunakan fitur notification.

3. Merancang aplikasi yang dapat menginput data aset, melihat dan mengirim pesan permintaan aset apabila dibutuhkan.

\section{LANDASAN TEORI}

\subsection{Sistem Informasi Eksekutif}

Menurut McLeod (2006), Sistem Informasi Eksekutif adalah suatu sistem yang memberikan informasi kepada manajer ditingkat yang lebih tinggi atas kinerja perusahaan secara keseluruhan.

Menurut Laudon (2002) sistem informasi eksekutif merupakan sistem informasi pada level strategis dari organisasi yang ditujukan bagi pengambilan keputusan tidak terstruktur melalui grafik dan komunikasi.

Sehingga Sistem Informasi Eksekutif adalah sebuah sistem yang memberikan informasi-informasi sangat penting kepada manajer untuk memonitori kinerja sebuah perusahaan sehingga dapat mengambil sebuah keputusan yang dapat meningkatkan kinerja perusahaan tersebut.

\subsubsection{Karateristik Sistem Informasi Eksekutif}

Sistem informasi eksekutif mempunyai beberapa karakteristik khusus. Menurut
Turban (2001) karateristik sistem informasi eksekutif sebagai berikut:

1. Drill Down

Salah satu kemampuan dari sistem informasi eksekutif yang paling berguna adalah menyediakan detil dari informasi yang telah diringkas. Dengan drill down para eksekutif dapat menilai dari gambaran sekilas dan kondisinya.

2. CSF (Critical Succes Factor)

Faktor-faktor penting yang harus dipertimbangkan dalam pencapaian tujuan organisasi. Faktor-faktor tersebut dapat berupa strategi untuk akan datang, sehingga dapat membantu eksekutif untuk mengambil keputusan.

3. Status Acces

Data atau laporan terakhir dapat diakses setiap saat dengan menggunakan jaringan, informasi yang penting adalah keterhubungan antara informasi tersebut.

4. Analisis

Pada sistem informasi eksekutif, kemampuan menganalisa informasi diperlukan. Eksekutif tidak harus mengambil data secara terus menerus tetapi cukup hanya sekali saja, kemudian menganalisanya sesuai dengan apa yang diinginkan.

5. Exception Reporting

Teknik pembuatan laporan yang hanya menampilkan item-item dalam bentuk yang berbeda dari biasanya, dengan tujuan memudahkan pembaca laporan. Seperti menggunakan grafik dalam sebuah laporan.

6. Use of Colors and Audio

Pemberitahuan mengenai hal-hal yang kritis bukan hanya menggunakan angka tetapi juga menggunakan warna, dengan menggunakan warna dapat memberitahu eksekutif atau pengguna mengenai masalah-masalah yang potensial yang harus mendapatkan perhatian.

7. Navigation of Information

Sebuah kemampuan yang memungkinkan data yang besar dapat dieksplorasi dengan cepat dan mudah. Untuk meningkatkan kemampuan ini dapat menggunakan peralatan hypermedia, yaitu multimedia yang terdiri atas teks, grafis, dan audio.

8. Communication 
Eksekutif dapat berkomunikasi dengan pihak lain melalui email atau sebagainya.

\subsection{Gangguan Listrik}

Dalam operasi sistem tenaga listrik sering terjadigangguan-gangguan yang dapat mengakibatkan terganggunya penyaluran tenaga listrik ke konsumen. Gangguan listrik adalah penghalang dari suatu system yang sedang beroperasi atau suatu keadaan dari system penyaluran tenaga yang menyimpang dari kondisi normal, sehingga aliran arus listrik keluar dari saluran yang seharusnya dan terjadi pemadaman listrik (Daman: 2009).

Kerugian yang diakibatkan terjadinya gangguan listrik adalah

a. Terputusnya kontinuitas pelayanan daya kepada para konsumen apabila gangguan itu sampai menyebabkan terputusnya suatu rangkaian atau menyebabkan pemadaman listrik.

b. Penurunan tegangan yang cukup besar menyebabkan rendahnya kualitas tenaga listrik dan merintangi kerja normal pada peralatan konsumen.

c. Pengurangan stabilitas system dan menyebabkan jatuhnya generator.

d. Merusak peralatan pada daerah terjadinya gangguan ini.

\subsection{Android}

Android adalah sebuah platform pertama yang betul-betul terbuka dan komprehensif untuk perangkat mobile, semua perangkat lunak yang ada difungsikan menjalankan device mobile tanpa memikirkan kendala kepemilikan yang menghambat inovasi pada teknologi mobile (Meier, 2008). Dalam definisi lain, android merupakan subset perangkat lunak untuk perangkat mobile yang meliputi sistem operasi, middleware, dan aplikasi inti dirilis oleh google. Sedangkan android SDK (Software Development Kit) menyediakan tools dan API yang diperlukan untuk mengembangkan aplikasi pada platform android dengan menggunakan bahasa pemograman java.

\subsection{Location Based Service}

Location Based Service (LBS) adalah sebuah layanan informasi yang dapat diakses oleh perangkat mobile seperti melalui internet dan juga dapat digunakan untuk merespon informasi yang disampaikan dari perangkat mobile (OGC, 2005). Adanya aplikasi LBS merupakan sebuah hasil kombinasi dari tiga teknologi yaitu New Information and Telecomunication Technologies (NICTS), Internet dan sistem informasi geografis (SIG) dengan menggunakan informasi data spasial. Ilustrasinya dapat dilihat pada gambar berikut.

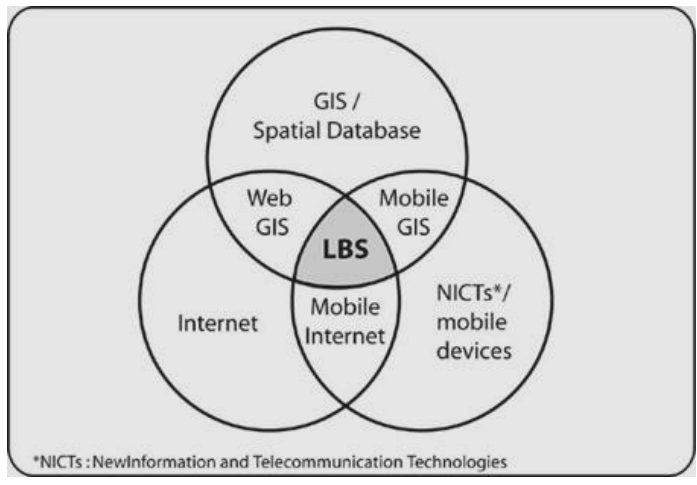

Gambar 1. Ilustrasi gambar Layanan Lokasi Berbasis

Dengan menggunakan Location Based Service (LBS) seseorang akan saling berkomunikasi dua arah komunikasi langsung sehingga para pengguna akan memberitahu penyedia layanan tentang suatu informasi seperti lokasi, dan informasi penting lainnya yang telah diminta sebelumnya. Hal ini akan membantu operator (provider) sebagai suatu layanan informasi untuk menyampaikan informasi kepada para pengguna. Jika pengguna ingin menggunakan beberapa teknologi LBS, oleh karena itu terdapat beberapa sub-system pendukung untuk mendukung penggunaanya dan akan dijelaskan pada gambar di bawah ini.

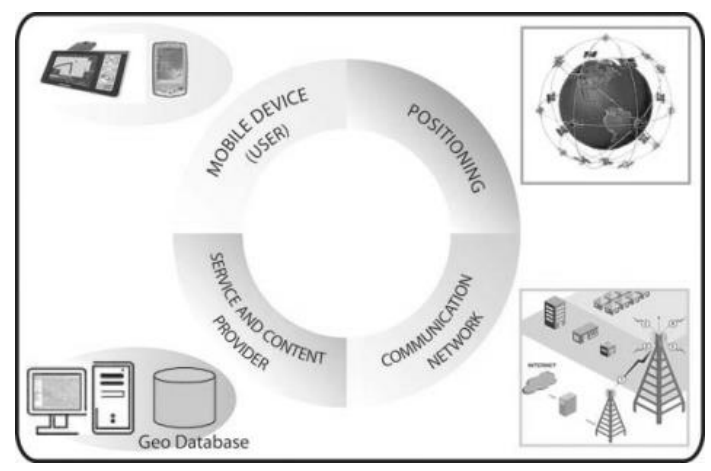

Gambar 2. Infrastruktur Location Based Service (Brimi-Combe, 2002)

1. Perangkat Mobile: sebuah perangkat dari pengguna untuk meminta informasi yang tersedia. Hasilnya dapat berupa suara, gambar, teks, dan sebagainya. Perangkat/ alatnya dapat berupa PDA, ponsel atau 
laptop. Perangkat/alat ini terkadang juga dapat digunakan sebagai salah satu unit navigasi atau kendaraan ketika sedang dalam perjalanan.

2. Jaringan komunikasi: komponen kedua yang dibutuhkan adalah jaringan komunkasi yang mengirim permintaan layanan dan data dari terminal mobile kepada penyedia layanan. Selain itu jaringan juga berfungsi utnuk mengembalikan informasi ke permintaan pengguna.

3. Komponen penentuan posisi: untuk permintaan penggunaan LBS posisi pengguna harus ditentukan. Pertama, Disini bedakan antara pelacakan (jaringan yang akan menentukan posisi anda) dan pemosisian (posisi evaluasi diri). Biasanya posisi pengguna didapat baik dengan menggunakan jaringan komunikasi mobile atau dengan menggunakan sistem penentuan posisi global (GPS). Kemungkinan untuk menentukan posisi lebih lanjutnya adalah jaringan lokal seperti Bluetooth atau WLAN, lencana aktif atau radio beacons (rambu radio). Metode penentuan posisi yang kedua khususnya dapat digunakan untuk navigasi indoor (dalam ruangan) seperti di dalam museum. Jika posisi ini tidak ditentukan secara otomatis dapat juga ditentukan secara manual

4. Penyedia Data \& Content: penyedia layanan biasanya tidak akan menyimpan dan menjaga semua informasi yang dapat diminta, oleh pengguna. Oleh karena itu, informasi basis data geografis dan data lokasi biasanya akan diminta dari tempat yang memiliki otoritas (misalnya lembaga pemetaan) atau mitra bisnis dan industri (yellow pages, perusahaan lalu lintas)

5. Location Based Service akan memungkinkan anda untuk menemukan lokasi perangkat anda saat ini, termasuk teknologi seperti GPS dan Google Cell yang merupakan teknologi yang berbasis lokasi. Anda dapat menentukan mana teknologi location-sensing yang digunakan secara ekplisit dengan nama yang implisit dengan mendefinisikan seperangkat kriteria bentuk akurasi, biaya dan persyaratan lainnya.

6. Peta dan Location Based Service menggunakan lintang dan bujur untuk menentukan lokasi geografis, tetapi lebih banyak pengguna cenderung memikirkan dalam bentuk alamat seperti yang terjadi pada pengguna Android, Android menyediakan geocoder yang mendukung maju dan balikan geocoding. Dengan menggunakan geocoding anda dapat mengubahnya bolak-balik antara lokasi lintang dan bujur serta alamat di dunia nyata.

\subsection{Teknologi Push}

Teknologi Push merupakan cara relatif yang baru untuk mengoptimalisasi pengiriman berita dan informasi ke desktop komputer, laptop, maupun HP pada internet maupun intranet. Metode push ini berbeda dengan email, real time data delivery vs penggunaan metode "store and forward" yang indentik dengan penundaan. yang digunakan oleh email dan untuk mengembangkan grafik kompleks, suara, hiperlink, dan data yang banyak tidak bisa dilakukan dalam teknologi email.

Melalui pendekatan push mungkin terdapat aplikasi-aplikasi bagi pemerintahan negara baik itu sebagai pengguna ataupun penyedia informasi. Diantaranya adalah menyediakan suatu cara alternatif dalam pemanfaatan teknologi ini seperti sistem penyiaran darurat yang mempertimbangkan teknologi push ini agar dapat selalu update keadaan lalu lintas yang sedang terjadi.

\subsubsection{Push vs Pull}

Beberapa pengamat telah mempertanyakan apakah metode "push"ini sebenarnya seperti e-mail. Setelah seluruh berbagai macam metode seperti "listservs" yang berfungsi untuk mengotomatiskan distribusi e-mail kepada seluruh pelanggan, pada dasarnya penyampaian informasi kepada pengguna tertentu apabila ada permintaan untuk setiap itemnya. Sedangkan prinsip mendasar listservs mirip yang ada pada "push" yang memungkinkan informasi jauh lebih kompleks dan grafis dibandingkan dengan e-mail yang hanya dapat mengakomodasi dan secara real-time untuk $e$ mail, dan tidak dirancang menggunakan sistem store dan forward.

\begin{tabular}{|c|c|}
\hline \multicolumn{2}{|c|}{ Tabel 2.1 ilustrasi pull vs push } \\
\hline Pull & Push \\
\hline $\begin{array}{l}\text { Buku dipilih secara } \\
\text { individual dari rak }\end{array}$ & $\begin{array}{l}\text { Buku disampaikan oleh } \\
\text { vendornya }\end{array}$ \\
\hline
\end{tabular}




\begin{tabular}{|c|c|}
\hline atau toko buku & $\begin{array}{l}\text { perpustakaan Indonesia, } \\
\text { dipillih berdasarkan } \\
\text { penerbitnya dan dikirim ke } \\
\text { pembaca yang sudah } \\
\text { berlangganan }\end{array}$ \\
\hline $\begin{array}{l}\text { Majalah atau surat } \\
\text { dapat dilihat di } \\
\text { kios-kios penjualan }\end{array}$ & $\begin{array}{lr}\text { Majalah dan surat kabar } \\
\text { disampaikan dengan } \\
\text { jadwal teratur oleh } \\
\text { vendornya }\end{array}$ \\
\hline $\begin{array}{lr}\text { Audio kaset } & \text { atau } \\
\text { CD dipilih } & \text { dan } \\
\text { dimainkan } & \text { oleh } \\
\text { pembeli } & \\
\end{array}$ & $\begin{array}{l}\text { Siaran radio, lagu yang } \\
\text { didengarkan dalam stasiun } \\
\text { radio dan mendengarkan } \\
\text { apa yang disiarkan }\end{array}$ \\
\hline $\begin{array}{l}\text { Video yang disewa } \\
\text { atau dibeli oleh } \\
\text { pembeli } \\
\text { pembeli tersebut } \\
\text { membuat pilihan } \\
\text { dari apa yang telah } \\
\text { tersedia pada rak- } \\
\text { rak }\end{array}$ & $\begin{array}{l}\text { Film atau konten lainnya } \\
\text { yang melalui siaran atau } \\
\text { televisi disampaikan } \\
\text { melalui siaran atau tv } \\
\text { berlangganan. Pembeli } \\
\text { lebih memilih siaran dan } \\
\text { menerima apa yang vendor } \\
\text { pilih. }\end{array}$ \\
\hline
\end{tabular}

\subsubsection{Konsep Teknologi Push Bekerja}

Penjelasan ini menggunakan PointCast untuk menggambarkan teknologi push. PointCast adalah perusahaan yang menyediakan software push dan sebagai Channel berita dan informasi lainnnya untuk para pengguna. Namun, prinsip-prinsip dasar teknologi push tercemin dalam beberapa produk dan mungkin disesuaikan dengan tujuan masing-masing. Penting untuk dicatat bahwa pengguna teknologi push tidak terbatas pada perusahaan komersial. Sebuah badan pemerintah dapat mendistribusikan informasi melalu jenis teknologi yang sama.

Push memerlukan software untuk front end user (software klien) dan software back end vendor (software server). Software lunak klien dan software server bekerja sama dengan salah satu lain. Software klien memiliki program yang tahu bagaimana meminta informasi, menerimanya, menyimpan dan menampilkannya. Vendor yang menyediakan informasi tersebut merupakan sebuah program yang memahami dan menyimpan permintaan yang diterima klien, melacak klien yang telah meminta channel tersebut, dan mengirimkan informasi melalui internet ke klien.

\subsection{Motode Pengembangan Sistem}

Incremental model adalah model pengembangan sistem pada software engineering berdasarkan software requirement yang dipecah menjadi beberapa fungsi atau bagian sehingga model pengembangannya secara increment atau bertahap (Roger Pressman, 2005).

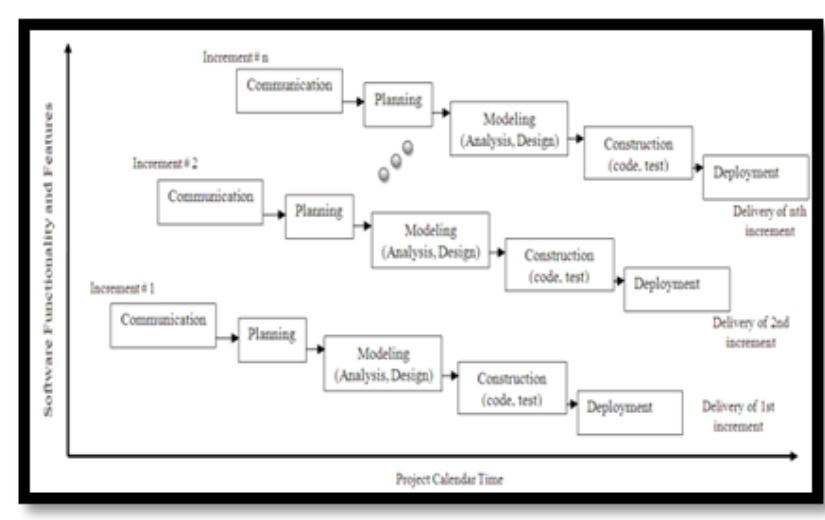

Gambar 3. Incremental Model

Tahapan-tahapan pada incremental adalah

1. Komunikasi

Proses tahapan awal yang dilakukan pada incremental model adalah penentuan kebutuhan atau analisa kebutuhan.

2. Tahap Perencanaan (Planning)

Tahap perencanaan merupakan kegiatan melakukan pengumpulan kebutuhan dalam pembuatan sistem ini. Seperti kebutuhan perangkat lunak (software) dan kebutuhan perangkat keras (hardware).

3. Modeling

Pada tahap ini, peneliti melakukan beberapa hal yang berkaitan dengan hal pemodelan, seperti perancangan usecase diagram, activity diagram, sequence diagram, dan class diagram

4. Konstruksi

Tahap ini merupakan tahap pembuatan aplikasi mengacu pada perancangan yang telah dilakukan pada tahap sebelumnya.

5. Deployment

Pada tahap ini diserahkan kepada pelanggan yang mengevaluasi produk yang dikirimkan dan memberikan umpan balik berdasarkan penilaian.

\subsubsection{Kelebihan Incremental Model}

a. Merupakan model dengan manajemen yang sederhana.

b. Pengguna tidak perlu menunggu sampai seluruh sistem dikirim untuk mengambil keuntungan dari sistem tersebut. Incremental yang pertama sudah memenuhi persyaratan mereka yang paling penting, sehingga perangkat lunak dapat segera digunakan. 
c. Resiko untuk kegagalan proyek secara keseluruhan lebih rendah, walaupun masalah masih dapat ditemukan pada beberapa incremental.

d. Nilai penggunaan dapat ditentukan pada setiap increment sehingga fungsionalitas sistem disediakan lebih awal.

e. Memiliki resiko lebih rendah terhadap keseluruhan pengembangan system.

f. Prioritas tertinggi pada pelayanan sistem adalah yang paling diuji.

\subsubsection{Kekurangan Incremental}

Terjadi kesulitan untuk memetakan kebutuhan pengguna ke dalam rencana spesifikasi masing-masing hasil increment.

\subsubsection{Karakteristik}

a. Kebutuhan user menjadi prioritas utama dimasukkan dalam awal increment.

b. Merupakan kombinasi waterfall model, yaitu dengan melakukan tahap-tahap waterfall model secara iterative.

c. Hasil atau produk dari increment 1 menjadi dasar perbaikan untuk increment 2, demikian seterusnya hingga produk dianggap sempurna.

d. Cocok digunakan dalam pengembangan system skala kecil, tidak lebih dari 200.000 baris coding.

e. Produk hasil increment pertama biasanya produk inti, yaitu produk yang memenuhi kebutuhan dasar.

\subsubsection{Alasan Menggunakan Incremental Model}

Dari beberapa macam mmodelmodel metode perangkat lunak, penulis memilih model incremental sebagai model pengembangan sistem untuk kasus yang diteliti dengan alasan sebagai berikut:

a. Requirement yang diberikan oleh PLN masih bersifat tidak jelas, sehingga untuk mendapatkan kejelasan dari requirement tersebut perlu dibuat tampilan sementara.

b. Aplikasi yang akan dibuat di PLN hanya terdiri dari 5 menu yakni, pengguna, peta, report, gangguan, dan peta.

c. Waktu yang diberikan untuk implementasi cukup singkat, dengan total waktu kurang lebih 6 buan terhitung dari tanggal 26 januari 2012 samapai tanggal 29 juni 2012 d. Aplikasi harus segera dapat
digunakan di lingkungan PLN.

\subsection{Unified Modeling Language (UML)}

UML (Unified Modeling Language) adalah 'bahasa' pemodelan untuk sistem atau perangkat lunak yang berparadigma 'berorientasi' objek (Nugroho, 2010).

UML merupakan sekumpulan pemodelan konvensi yang digunakan untuk menentukan atau menggambarkan sebuah sistem perangkat lunak dalam kaitannya dengan objek (Whitten et al, 2004:430).

Unified Modelling Language (UML) adalah sebuah "bahasa" yg telah menjadi standar dalam industri untuk visualisasi, merancang dan mendokumentasikan sistem piranti lunak (Dharwiyanti,2003).

Dari definisi diatas dapat ditarik kesimpulan bahwa UML adalah tools pemodelan dalam perancangan perangkat lunak yang digunakan untuk menggambarkan suatu sistem berorientasi objek.

\subsection{Pengujian Perangkat Lunak}

Pengujian black-box berfokus pada persyaratan fungsional perangkat lunak. Dengan demikian, pengujian perangkat lunak memungkinkan peneliti mendapatkan serangkaian kondisi input yang sepenuhnya menggunakan persyaratan fungsional untuk suatu program. Pengujian black-box bukan suatu alternatif dari teknik white-box, tetapi merupakan pendekatan komplementer yang kemungkinan besar mampu mengungkap kelas kesalahan daripada metode white-box.

Pengujian black-box berusaha menemukan kesalahan dalam ketegori sebagai berikut:

a. Fungsi-fungsi yang tidak benar atau hilang

b. Kesalahan interface

c. Kesalahan dalam struktur data atau akses database eksternal

d. Kesalahan kinerja

e. Inisialisasi dan kesalahan terminasi Tidak seperti pengujian white-box, yang dilakukan pada saat awal proses pengujian, pengujian black-box cenderung diaplikasikan selama tahap akhir pengujian. Karena pengujian black-box memperhatikan struktur kontrol, maka perhatian terfokus pada domain informasi. pengujian didesain untuk menjawab pertanyaan-pertanyaan berikut:

1. Bagaimana validitas fungsional diuji? 
2. Kelas input apa yang akan membuat test case menjadi baik?

3. Apakah sistem sangat sensitif terhadap harga input tertentu?

4. Bagaimana batasan dari suatu data diisolasi?

5. Kecepatan data apa dan volume data apa yang dapat ditolerir oleh sistem?

6. Apa pengaruh kombinasi tertentu dari data terhadap sistem informasi?

\section{METODOLOGI PENELITIAN}

\subsection{Metode Pengumpulan Data}

Metode pengumpulan data yang digunakan di dalam penelitian ini adalah studi pustaka dan literatur sejenis, dan studi lapangan yang berupa kuesioner, observasi dan wawancara.

\subsection{Metode Pengembangan Sistem}

Dalam tahap pengembangan Aplikasi Sistem Informasi Eksekutif Gangguan Pada Gardu Listrik di PT PLN Area Bandung mengunakan Platform Android Berbasis Sistem Informasi Geografi (SIG), peneliti menggunakan metode incemental

\subsubsection{Communication (Komunikasi)}

Pada tahapan ini merupakan aktivitas komunikasi dengan pihak-pihak manajerial PT. PLN Area Bandung mengenai proses penentuan kebutuhan aplikasi ini.

\subsubsection{Planning (Perencanaan)}

Tahapan perencanaan merupakan aktivitas pengumpulan kebutuhan dalam pembuatan aplikasi ini yang meliputi manajemen dan pelaksanaan teknis, manajemen resiko, sumber daya yang dibutuhkan, produk yang dihasilkan. Peneliti akan melakukan beberapa hal yang diperlukan, yaitu:
a. Analisa sistem berjalan.
b. Identifikasi masalah.
c. Analisa kebutuhan sistem.
d. Tujuan Pembangunan sistem.
e. Analisa proses yang diusulkan.

\subsubsection{Modelling (Pemodelan)}

Pada tahap ini, peneliti melakukan beberapa hal yang berkaitan dengan hal pemodelan, seperti perancangan usecase diagram, activity diagram, sequence diagram, dan class diagram.

\subsubsection{Construction (Konstruksi)}

Pada tahap ini, peneliti melakukan pengkodean dan mengkonstruksikan sebuah aplikasi menggunakan perangkat lunak yang telah ditentukan. Pada tahap ini juga dilakukan uji coba terhadap aplikasi. Uji coba dilakukan dengan metode Black box testing.

\subsubsection{Deployment (Penyebaran)}

Kegiatan penyebaran meliputi dua tindakan, yaitu: pengiriman (Delivery), dan umpan balik (feedback). Karena model proses perangkat lunak yang digunakan bersifat interatif, sehingga penyebaran terjadi tidak hanya sekali, tapi beberapa kali selama aplikasi tersebut terus mengalami penyempurnaan dari model sebelumnya.

\section{PEMBAHASAN \\ 4.1 Metode Pengembangan Sistem \\ 4.1.1 Communication (Fase Komunikasi)}

Pada fase ini, peneliti melakukan serangkaian wawancara untuk mendapatkan informasi mengenai sistem yang berjalan pada PT.PLN, sehingga peneliti dapat mengidentifikasi permasalahan yang terjadi.

\subsubsection{Planning (Fase Perencanaan)}

\subsubsection{Analisis Sistem Berjalan}

Setelah melakukan wawancara dan observasi di PT.PLN APJ Bandung pada tanggal 26 Januari 2012 di bagian manajerial dan junior analis sistem teknologi informasi, dapat digambarkan seperti di bawah ini:

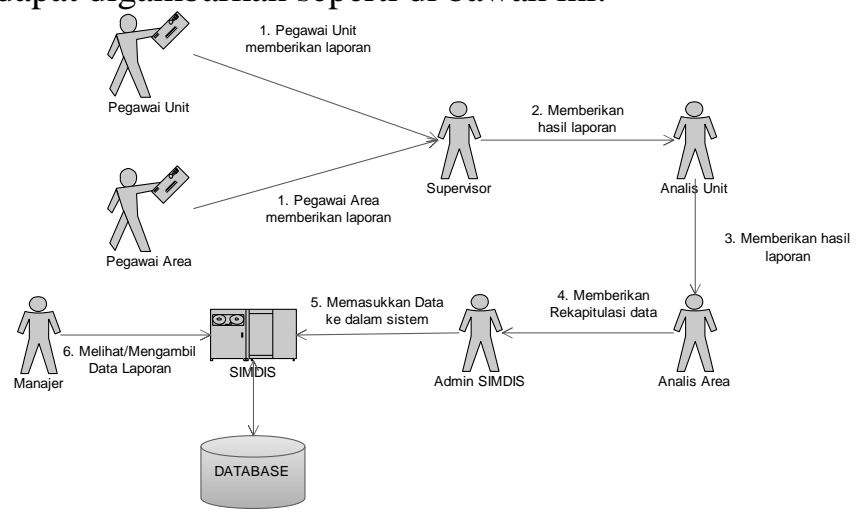

Gambar 4. Anaisis Sistem Berjalan

Pada Gambar 4 dapat dijelaskan bahwa pegawai unit dan pegawai area selalu memberikan laporan-laporan perusahaan kepada supervisor yang kemudian diserahkan kepada analis unit untuk diproses, setelah laporan-laporan tersebut di proses oleh analis unit kemudian dikirim ke analis area dan laporan-laporan tersebut digabungkan dan direkap dari semua unit area bandung. Setelah laporan-laporan unit direkap oleh analis area, laporan-laporan tersebut diserahkan kepada admin SIMDIS yang kemudian akan di upload ke dalam SIMDIS. Setelah masuk ke dalam database SIMDIS laporan-laporan tersebut 
dapat diakses oleh setiap divisi atau bagian manejerial yang memerlukan laporan tersebut.

\subsubsection{Identifikasi Masalah}

Dari hasil analisis yang dilakukan pada tanggal 26 januari 2012 sampai pada tanggal 29 juni 2012, diketahui bahwa proses permintaan laporan-laporan tersebut masih bersifat internal walaupun sudah menggunakan SIMDIS sehingga permintaan laporan-laporan perusahaan masih memakan waktu yang cukup lama apabila pihak menejerial berada di luar kantor PT. PLN Area Bandung atau kecerobohan pegawai yang telat menyerahkan laporan-laporan tersebut ke pihak admin SIMDIS, dan masalah lain ditemukan apabila teknisi lapangan sedang memperbaiki jaringan listrik dan mencari persediaan aset yang dibutuhkan untuk proses perbaikan tersebut dan pencatatan laporan gangguan listrik masih menggunakan cara manual sehingga masih dapat terjadinya kehilangan berkas laporan gangguan listrik.

\subsubsection{Analisis Kebutuhan Sistem 1. Identifikasi Strategi IT}

Tabel 4.1 Identifikasi Strategi IT

\begin{tabular}{|c|c|c|c|}
\hline No. & Judul & Tolak Ukur & $\begin{array}{c}\text { Sasaran } \\
\text { Perbaikan }\end{array}$ \\
\hline 1. & $\begin{array}{l}\text { Laporan- } \\
\text { laporan } \\
\text { perusahaan }\end{array}$ & $\begin{array}{l}\text { Laporan- } \\
\text { laporan } \\
\text { perusahaan } \\
\text { hanya bisa } \\
\text { diakses } \quad \text { di } \\
\text { dalam } \\
\text { gedung PT. } \\
\text { PLN Area } \\
\text { bandung }\end{array}$ & $\begin{array}{l}\text { Mempermudah } \\
\text { memperoleh } \\
\text { laporan-laporan } \\
\text { perusahaan } \\
\text { walaupun } \\
\text { sedang berada } \\
\text { di luar kantor }\end{array}$ \\
\hline 2. & $\begin{array}{l}\text { Persediaan } \\
\text { aset }\end{array}$ & $\begin{array}{l}\text { Penyimpanan } \\
\text { daftar } \\
\text { persediaan } \\
\text { aset masih } \\
\text { bersifat } \\
\text { manual }\end{array}$ & $\begin{array}{l}\text { Penyimpanan } \\
\text { dalam bentuk } \\
\text { digital ke dalam } \\
\text { database. }\end{array}$ \\
\hline 3. & $\begin{array}{l}\text { Gangguan } \\
\text { listrik }\end{array}$ & $\begin{array}{l}\text { Kemungkina } \\
\text { n Berkas } \\
\text { Rusak, atau } \\
\text { hilang. }\end{array}$ & $\begin{array}{l}\text { Penyimpanan } \\
\text { dalam bentuk } \\
\text { digital ke dalam } \\
\text { database. }\end{array}$ \\
\hline
\end{tabular}

2. Identifikasi Pola Solusi

Tabel 4.2 Identifikasi Pola Solusi

\begin{tabular}{|c|c|c|}
\hline no & Sasaran Perbaikan & Pola Solusi \\
\hline 1. & $\begin{array}{c}\text { Kemudahan memperoleh } \\
\text { laporan-laporan }\end{array}$ & $\begin{array}{l}\text { Menggunakan aplikasi } \\
\text { yang bersifat mobile yang }\end{array}$ \\
\hline
\end{tabular}

\begin{tabular}{|l|l|l|}
\hline & perusahaan & $\begin{array}{l}\text { dapat diakses dimanapun } \\
\text { dan menambahkan fitur } \\
\text { notification. }\end{array}$ \\
\hline 2. & $\begin{array}{l}\text { Penyimpanan data aset } \\
\text { dalam bentuk digital ke } \\
\text { dalam database. }\end{array}$ & $\begin{array}{l}\text { Membuat form pengisian } \\
\text { data aset yang bersifat } \\
\text { dinamis ke dalam sistem }\end{array}$ \\
\hline 3. & $\begin{array}{l}\text { Penyimpanan laporan } \\
\text { gangguan listrik dalam } \\
\text { bentuk digital dalam } \\
\text { database. }\end{array}$ & $\begin{array}{l}\text { Membuat form pengisian } \\
\text { gangguan listrik yang } \\
\text { bersifat dinamis dan } \\
\text { menambahkan fitur } \\
\text { navigasi untuk } \\
\text { mempermudah } \\
\end{array}$ \\
& $\begin{array}{l}\text { menemukan lokasi } \\
\text { gangguan listrik dan fitur } \\
\text { notification. }\end{array}$ \\
\hline
\end{tabular}

\subsubsection{Analisis Proses yang Diusulkan}

Adapun sistem yang diusulkan adalah menitik beratkan bagaimana user area dan user unit dapat memasukan laporan-laporan yang dibutuhkan pihak menejerial tepat waktu. Proses awal adalah administrator menentukan user unit dan user area maupun pihak menejerial yang dapat mengakses aplikasi ini. Mengingat laporan-laporan perusahaan bersifat rahasia dan penting maka semua informasi data siapa yang membuat, siapa yang mengakakses harus jelas dan akurat, karena nantinya akan dipertanggungjawabkan semua kebenaran data laporan yang diinput ke dalam aplikasi. Setelah itu, user unit dan user area yang sudah ditentukan harus login terlebih dahulu, ketika user akan menginput laporan-laporan perusahaan maka user dapat memilih page gangguan listrik, dan dapat menginput data aset jaringan listrik. Sedangkan untuk manajerial hanya bisa melihat dan mendownload laporan-laporan perusahaan dan menggunakan fitur navigasi.

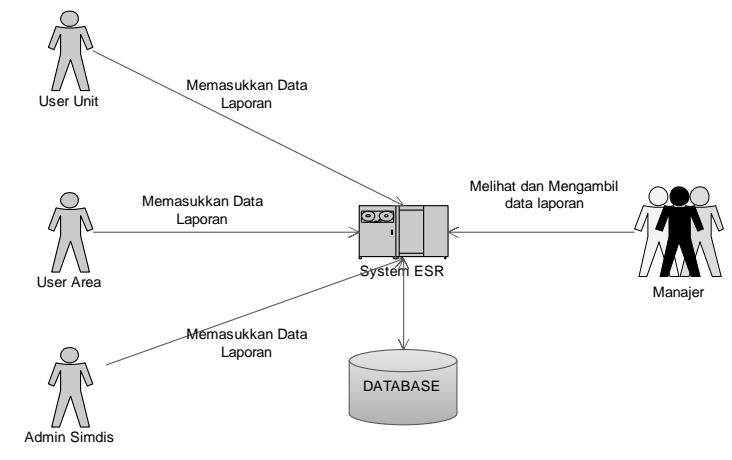

Gambar 5. Analisa Proses Sistem Usulan

\subsubsection{Construction 4.2.4.1 Coding}


Pada penelitian ini kode program terbagi menjadi dua bagian, kode program frontend dan kode program back-end. Penjelasannya sebagai berikut:

a. Kode Program Front End

Java Android, kode program pada Java Android ini berfungsi untuk menampilkan aplikasi mobile beserta fungsi navigasi, upload, download dan sebagainya.

b. Kode Program Back End

PHP, kode program pada PHP ini berfungsi untuk mengambil dan menyimpan data ke database

\subsubsection{Testing}

Pada tahap pengujian dilakukan dengan cara Blackbox Testing. Cara pengujian dilakukan dengan menjalankan aplikasi Sistem Informasi Eksekutif kemudian melihat output-nya apakah telah sesuai dengan hasil yang diharapkan.

Pengujian aplikasi ini dilakukan oleh pihak menejerial, pegawai area atau unit dan pegawai lapangan. Penguji diberikan dua formulir yakni formulir pengujian fungsionalitas aplikasi dan formulir pengujian penerimaan yang berisi kepuasan atau keberhasilan aplikasi (acceptance test).

\subsubsection{Deployment (Fase Penyebaran)}

Setelah tahap desain, coding selesai dan telah di lakukan testing, maka untuk tahap berikutnya adalah deployment, yaitu tahap penyerahan core aplikasi kepada pihak PT.PLN Area Bandung.

\subsection{Kesimpulan}

\section{PENUTUP}

Dari penelitian yang telah diuraikan oleh peneliti, maka dapat ditarik kesimpulan sebagai berikut:

1. Aplikasi yang dibuat dengan teknologi GIS dapat membantu mengetahui lokasi gangguan dengan menginput lattitude dan longitude gardu listrik oleh admin sehingga pihak menejerial dapat meihat lokasi gardu listrik dan dapat menggunakan fitur navigasi dengan memilih lokasi gardu yang mengalami gangguan.

2. Aplikasi ini dibuat dengan fitur notification yang dapat memunculkan sebuah allert berupa suara dan perubahan lampu LED HP apabila terdapat laporan yang masuk sehingga laporan tersebut sesuai dengan waktu kejadian
3. Dengan aplikasi ini admin, user area dan unit dapat menginput persediaan aset di setiap unit atau area, sehingga pegawai lapangan mengetahui persediaan aset dan mengirim pesan meminta aset tersebut apabila terjadi kerusakan di suatu wilayah menggunakan aplikasi ini.

\subsection{Saran}

Sistem ini tentu saja masih belum sempurna. Masih banyak hal yang dapat dilakukan untuk mengembangkan sistem ini agar menjadi lebih baik lagi, antara lain:

1. Diharapkan pengembangan selanjutnya dapat menggambarkan secara detail peta jaringan listrik kota Bandung.

2. Untuk pengembangan selanjutnya diharapkan aplikasi sudah terintegrasi dengan alat pendeteksi gangguan yang berada di setiap gardu, sehingga langsung mengetahui gangguan tersebut tanpa menunggu laporan dari konsumen.

3. Diharapkan pengembangan selanjutnya aplikasi ini dapat membantu setiap konsumen untuk memperoleh pelayanan terbaik dari pihak PLN.

\section{DAFTAR PUSTAKA}

[1] Daman Suswanto, 2009. Sistem Distribusi Tenaga Listrik. Universitas Negeri Padang, Padang.

[2] Jeffery L. Whitten, Lonnie D. Bentley \& Kevin C. Dittman. 2004. Metode Desain dan Analisis Sistem, Ed. I. Yogyakarta: Andi.

[3] Jogiyanto, HM. 2008. Metodologi Penelitian Sistem Informasi. Yogyakarta: Andi.

[4] Edhy Sutanta. 2011. Basis Data dalam Tinjauan Konseptual. Yogyakarta: Andi

[5] Kadir, Abdul. 2003. Pengenalan Sistem Informasi. Yogyakarta: Andi.

[6] Laudon, K.C \& Laudon, J.P. (2008) Sistem Informasi Manajemen, Jakarta, Salemba Empat

[7] Nugroho, Bunafit. 2005. Database Relational dengan MySQL. Yogyakarta: Andi

[8] Pressman, Roger, S. 2002. Rekayasa Perangkat Lunak Pendekatan Praktis (buku I). Yogyakarta: Andi.

[9] Rosa \& Shalahuddin, M. 2011. Modul Pembelajaran Rekayasa perangkat Lunak (Terstruktur dan Berorientasi Objek). Bandung: Modula. 
[10] Safaat, Nazrudin. 2011. Android: Pemrograman Aplikasi Mobile Smartphone dan Tablet PC. Bandung: Informatika

[11] Sholiq. 2006. Pemodelan Sistem Informasi Berorientasi Objek dengan UML. Yogyakarta: Graha Ilmu.

[12] Rina, Chera, Nurul, dan Doli. 2011. Incremental Model. Makalah tidak diterbitkan: Sistem Informasi Universitas Gundarma

[13] www.pln.co.id, Juni 2012, pukul 13:00 WIB. 